\title{
Effect of in-vitro heat stress on prostaglandin and protein secretion by endometrium from pregnant and cyclic gilts at Day 14 after oestrus*
}

\author{
T. S. Gross $†$, D. J. Putney†, F. W. Bazer $\ddagger$ and W. W. Thatcher $\dagger$ \\ $\dagger$ Dairy Science Department and $\ddagger$ Department of Animal Science, University of Florida, Gainesville, \\ FL 32611, USA
}

\begin{abstract}
Summary. Endometrium from cyclic $(\mathrm{N}=4)$ and pregnant $(\mathrm{N}=4)$ gilts at Day 14 after oestrus was placed into three bilateral perifusion devices which allow separate perifusion of luminal and myometrial sides. Perifused endometrium was subjected to 39 or $42^{\circ} \mathrm{C}$. Incorporation of $\left[{ }^{3} \mathrm{H}\right]$ leucine into secreted and tissue proteins by endometrial explants following incubation at 39 or $42^{\circ} \mathrm{C}$ was examined using trichloroacetic acid (TCA) precipitation and one-dimensional SDS polyacrylamide gel electrophoresis. Secretion of PGF was greater from the myometrial side for cyclic gilts (endocrine orientation), but greater from the luminal side for pregnant gilts (exocrine orientation). Regardless of reproductive status or endometrial side, heat stress induced a rapid increase $(P<0.01)$ in PGF secretion rates. However, PGF secretion in response to heat stress was greater $(P<0.01)$ from the myometrial side and greater $(P<0.01)$ for pregnant gilts. PGF secretion rates increased by $63 \%$ and $42 \%$ from the luminal side, and $40 \%$ and $156 \%$ from the myometrial side in response to heat stress for cyclic and pregnant gilts, respectively (status $\times$ treatment $\times$ side interaction; $P<0.01$ ). Heat stress did not alter incorporation of $\left[{ }^{3} \mathrm{H}\right]$ leucine into secreted proteins regardless of reproductive status, while incorporation into tissue proteins was decreased $(P<0.05)$ by heat stress for pregnant gilts, but not altered for cyclic gilts. Heat stress, in vitro, redirects PGF secretion for endometria of pregnant gilts from an exocrine to an endocrine orientation where it would be available to effect luteolysis and compromise the establishment of pregnancy.
\end{abstract}

Keywords: pig; heat stress; endometrium; prostaglandins; perifusion; proteins

\section{Introduction}

Transient infertility often occurs during periods of environmental heat stress in cattle (Thatcher, 1974), sheep (Dutt, 1963) and pigs (Trujano \& Wrathall, 1985). Embryos are extremely sensitive to the harmful effects of maternal hyperthermia, which is reflected by an increase in the frequency of nonviable, abnormal and retarded embryos (Trujano \& Wrathall, 1985; Putney et al., 1988a). In-vivo heat stress of gilts between Days 8 and 16 of pregnancy increased concentrations of 13,14dihydro-15-keto PGF-2 $\alpha$ (PGFM) in plasma (Wettemann et al., 1988). This may account for the reduced concentrations of progesterone in plasma during Days 13-19 (Hoagland \& Wettemann, 1984). Increased concentrations of systemic PGFM may reflect increased uterine secretion of PGF in response to heat stress.

The establishment of pregnancy, involves maintenance of luteal function due to suppression or alteration of uterine luteolytic mechanisms. In cattle (Gross et al., 1988c) and sheep (Bazer et al.,

\footnotetext{
${ }^{*}$ Reprint requests to: $\mathrm{F}$. W. Bazer.
} 
1989) the anti-luteolytic mechanisms, during early pregnancy, involves an attenuation of endometrial responsiveness to stimulators of prostaglandin synthesis (i.e. oxytocin). However, pig endometrium is capable of responding to oxytocin with increased PG secretion regardless of reproductive status (Gross et al., 1988a). Bazer \& Thatcher (1977) proposed that a reorientation of endometrial prostaglandin (PG) F release into the uterine lumen (exocrine mode) might occur at the onset of pregnancy in pigs. Gross et al. (1988a) demonstrated in vitro that PG secretion for perifused endometrial tissue was primarily in an endocrine direction, towards the myometrium and the uteroovarian vasculature, during the oestrous cycle. However, during early pregnancy, PG secretion was primarily exocrine, towards the uterine lumen. Such a reorientation in secretion might prevent release of PGF into the uterine vasculature and allow CL maintenance. Heat stress might alter uterine and embryonic function in a manner that would attenuate the antiluteolytic processes that occur during early pregnancy.

Endometrial protein secretions provide nutrients essential for conceptus development during early pregnancy (Bazer, 1975). Therefore, heat stress might also alter endometrial protein synthesis and secretion in a manner that would contribute to pregnancy failure and embryonic mortality.

The present study examined whether in-vitro heat stress alters endometrial protein synthesis or secretion and the orientation of secretion of PGF by endometrial tissue from pregnant and cyclic gilts at Day 14 after oestrus.

\section{Materials and Methods}

Materials. Radioisotopes of $\mathrm{L}-\left[4,5-{ }^{3} \mathrm{H}\right] \mathrm{leucine}$ (sp. act. $150 \mathrm{Ci} / \mathrm{mmol}$ ) and $\left[5,6,8,1 \mathrm{t}, 12,14,15-{ }^{3} \mathrm{H}\right] \mathrm{PGF}-2 \alpha$ (sp. act. $160-180 \mathrm{Ci} / \mathrm{mmol}$ ) were purchased from Amersham Corporation (Arlington Heights, IL, USA). Oxytocin was purchased from Sigma Chemical Company (St Louis, MO, USA). Antiserum to PGF was provided by T. G. Kennedy. Dialysis tubing was purchased from Spectrum Medical (Los Angeles, CA, USA). Supplies for polyacrylamide gel electrophoresis (PAGE) were as follows: Tris and $N, N, N^{N}, N^{\prime}$-tetramethyl ethylenediamine (TEMED) were purchased from Sigma Chemical Co.; sodium salicylate, 2-mercaptoethanol, glycine and ammonium peroxydisulphate were purchased from Fisher Scientific (Orlando, FL, USA); acrylamide, urea, dithiothreitol and sodium dodecyl sulphate (SDS) were purchased from Research Organics (Cleveland, OH, USA); and bis-acrylamide, gelatin and Tween-20 were purchased from Bio-Rad (Richmond, CA, USA).

A modified minimum essential medium (MEM; custom formula No. 87-5007) and other medium ingredients were purchased from Gibco (Grand Island, NY, USA). Medium was prepared as described by Basha et al. (1980) and supplemented with $1 \%(\mathrm{v} / \mathrm{v})$ Gibco MEM vitamin solution. For cultures in the presence of $\left[{ }^{3} \mathrm{H}\right]$ leucine, medium was prepared at a reduced leucine content ( $10 \%$ of the normal concentration).

Tissue collection. Sexually mature crossbred (Duroc $\times$ Yorkshire $\times$ Hampshire) gilts were observed for oestrous behaviour in the presence of a boar between 07:30 and 08:00 h each day. Day of onset of oestrus was designated Day 0 . Gilts were either mated by natural service when detected in oestrus and at $12 \mathrm{~h}$ and $24 \mathrm{~h}$ after onset of oestrus (pregnant, $\mathrm{N}=4$ ) or not mated (cyclic, $\mathrm{N}=4$ ). All gilts were hysterectomized at Day 14 after oestrus. Reproductive tracts were removed rapidly and flushed with a modified Minimal Essential Medium (MEM) to collect conceptuses and confirm reproductive status. Endometrium was dissected from myometrial tissue over a side area of approximately $8-10 \mathrm{~cm}^{2}$.

Perifusions. Endometrium was placed into sterile Krebs-Ringer-bicarbonate solution (KRB; Sigma Chemical Co., with $0.1 \mathrm{M}-\mathrm{CaCl}_{2}$ and $0.2 \mathrm{M}-\mathrm{NaHCO}_{3}$ ) which had been gassed with $\mathrm{O}_{2}: \mathrm{CO}_{2}$ (95:5), washed twice with fresh $\mathrm{KRB}$ and dissected into three pieces of approximately $2 \mathrm{~cm}^{2}$. Each endometrial sample was placed into a bilateral perifusion device which allowed separation of myometrial and luminal sides so that each was perifused separately in a $0.5 \mathrm{ml}$ hemi-chamber (Lacroix \& Kann, 1983; Gross et al., 1988a). Tissue was anchored into each device with the aid of 4 needles. Each chamber was placed into a $39^{\circ} \mathrm{C}$ water bath, attached to dual $60 \mathrm{ml}$ syringes containing freshly gassed $\mathrm{KRB}$, and perifused at a rate of $3 \mathrm{ml} / 10 \mathrm{~min}$ for $5 \mathrm{~h}$ using a Harvard infusion pump system. Fractions ( $3 \mathrm{ml}$ ) were collected every $10 \mathrm{~min}$ for a total of 30 fractions.

Each of the three endometrial perifusion preparations within each gilt were subjected to a different temperature and oxytocin ( $1 \mathrm{i.u} / \mathrm{ml} \mathrm{KRB}$ ) treatment sequence: (1) control-oxytocin: $1 \mathrm{~h}$ at $39^{\circ} \mathrm{C}, 2 \mathrm{~h}$ at $39^{\circ} \mathrm{C}, 0.5 \mathrm{~h}$ at $39^{\circ} \mathrm{C}$ with oxytocin, $0.5 \mathrm{~h}$ at $39^{\circ} \mathrm{C}$ and $1 \mathrm{~h}$ at $39^{\circ} \mathrm{C}$; (2) heat-oxytocin; $1 \mathrm{~h}$ at $39^{\circ} \mathrm{C}, 2 \mathrm{~h}$ at $42^{\circ} \mathrm{C}, 0.5 \mathrm{~h}$ at $42^{\circ} \mathrm{C}$ with oxytocin, $0.5 \mathrm{~h}$ at $42^{\circ} \mathrm{C}$ and $1 \mathrm{~h}$ at $39^{\circ} \mathrm{C}$; and (3) heat-saline: $1 \mathrm{~h}$ at $39^{\circ} \mathrm{C}, 2 \mathrm{~h}$ at $42^{\circ} \mathrm{C}, 0.5 \mathrm{~h}$ at $42^{\circ} \mathrm{C}$ with saline, $0.5 \mathrm{~h}$ at $42^{\circ} \mathrm{C}$ and $1 \mathrm{~h}$ at $39^{\circ} \mathrm{C}$. Temperature treatments were imposed on endometrium by placing perifusion devices in water baths maintained at 39 or $42^{\circ} \mathrm{C}$ and perifusion of tissues with KRB maintained at 39 or $42^{\circ} \mathrm{C}$.

RIA procedures. Fractions were analysed for PGF using a direct radioimmunoassay (RIA) procedure (Gross et al., $1988 \mathrm{~b}$ ) and an antibody characterized by Kennedy (1985). Cross-reactivities of the PGF- $2 \alpha$ antiserum were; $94 \%$ for 
PGF- $1 \alpha, 2 \cdot 4 \%$ for PGE-2, and $<0 \cdot 1 \%$ for PGFM and arachidonic acid. Because of the high cross-reactivity with PGF- $1 \alpha$, the assay results are listed as concentrations of PGF. Inter- and intra-assay coefficients of variation were $9 \cdot 8 \%$ and $11 \cdot 6 \%$, respectively.

Incorporation of $\left.{ }^{3} \mathrm{H}\right]$ leucine into proteins. Endometrial tissue was dissected into approximately $1 \mathrm{~mm}^{3}$ pieces and placed $\left(500 \mathrm{mg}\right.$ ) into a Petri dish containing $0.1 \mathrm{mCi} \mathrm{L}-\left[4,5-{ }^{3} \mathrm{H}\right]$ leucine and $15 \mathrm{ml} \mathrm{MEM}$. Tissues were incubated for $8 \mathrm{~h}$ at 39 or $42{ }^{\circ} \mathrm{C}$ on a rocker platform under an atmosphere of $47.5 \% \mathrm{O}_{2}, 50 \% \mathrm{~N}_{2}$ and $2.5 \% \mathrm{CO}_{2}$. At the conclusion of incubation, tissue and medium were separated by centrifugation $\left(3500 \mathrm{~g}, 4^{\circ} \mathrm{C}, 30 \mathrm{~min}\right)$ and stored at $-70^{\circ} \mathrm{C}$ until analysed.

Radiolabelled protein determination. Incorporation of radiolabelled leucine into secreted (medium) and intracellular (tissue) proteins was determined by trichloroacetic acid (TCA) precipitation. Tissue from incubations with $\left[{ }^{3} \mathrm{H}\right]$ leucine was solubilized in $50 \mathrm{~mm}$-Tris-acetate buffer $(2 \mathrm{ml}$ buffer $/ 500 \mathrm{mg}$ tissue $)$ containing $1 \mathrm{~mm}$-phenylmethylsulphonyl-fluoride, $1 \mathrm{~mm}$-ethylenediamine-tetraacetic acid and $2 \%(\mathrm{v} / \mathrm{v})$ Nonidet P-40. Aliquants $(0.05 \mathrm{ml})$ of medium and solubilized tissue were each placed and dried onto Whatman $3 \mathrm{MM}$ paper that had been saturated previously with $20 \%$ TCA (w/v). Precipitation of proteins onto the filter paper and removal of non-proteinaceous compounds was accomplished by serial washing of filter paper with $20 \%$ and $5 \%$ TCA followed by $95 \%$ ethanol as described by Mans \& Novelli (1961). Radioactivity of precipitated protein was determined by scintillation spectrometry.

Electrophoresis. Medium from endometrial explants containing $\left[{ }^{3} \mathrm{H}\right]$ leucine was dialysed extensively ( 3 changes of 41) against distilled water using dialysis tubing with an $M_{\mathrm{r}}$ exclusion limit of 6000-8000 to remove low $M_{\mathrm{r}}$ compounds and unincorporated radiolabelled precursors. Dialysed samples of medium and samples of solubilized tissue were each examined qualitatively using sodium dodecyl sulphate (SDS), polyacrylamide gel electrophoresis (SDS-PAGE). One-dimensional SDS-PAGE was performed using the buffer system of Laemmli (1970) with $12 \cdot 5 \%$ (w/v) polyacrylamide gels. Samples containing 100000 d.p.m. were lyophilized, dissolved in $0.1 \mathrm{ml}$ of dissociating buffer containing $1 \%(\mathrm{w} / \mathrm{v})$ SDS and $5 \%(\mathrm{v} / \mathrm{v}) 2$-mercaptoethanol, and boiled $\left(3 \mathrm{~min}\right.$; boiling point approximately $\left.96^{\circ} \mathrm{C}\right)$ before being loaded onto gels. Proteins were localized by staining with Coomassie Blue R-250 and fluorography as described by Roberts et al. (1984). Fluorographs were prepared with Kodak XAR film using sodium salicylate as a fluor (Chamberlain, 1979).

Statistical analysis. Data were analysed by Least Squares Analysis of Variance using the General Linear Models procedure of the Statistical Analysis System (SAS, 1985). Secretion rates of PGF for luminal, myometrial or luminal + myometrial sides of endometrium were analysed for the total perifusion sequence and for the following perifusion treatment periods (thermoneutral $\left[39^{\circ} \mathrm{C}\right]$, heat stress $\left[42^{\circ} \mathrm{C}\right]$, oxytocin, saline): (1) $1 \mathrm{~h}$ at $39^{\circ} \mathrm{C}$, (2) $2 \mathrm{~h}$ at 39 or $42^{\circ} \mathrm{C},(3) 0.5 \mathrm{~h}$ at $39^{\circ} \mathrm{C}$ with oxytocin or at $42^{\circ} \mathrm{C}$ with saline or oxytocin, (4) $0.5 \mathrm{~h}$ at 39 or $42^{\circ} \mathrm{C}$, and (5) $1 \mathrm{~h}$ at $39^{\circ} \mathrm{C}$. Secretion rates were also analysed for combinations of these various perifusion treatment periods: periods $1+2$, periods $2+3$, periods $3+4$, and periods $4+5$. The statistical model components for analyses of PGF secretion rates were: status (pregnant or cyclic), status (gilt), treatment (temperature and oxytocin), status $\times$ treatment, status (gilt) $\times$ treatment, side, status $\times$ side, status (gilt) $\times$ side, treatment $\times$ side, status $\times$ treatment $\times$ side, status (gilt) $\times$ treatment $\times$ side, time, status $\times$ time, treatment $\times$ time, side $\times$ time, status $\times$ treatment $\times$ time, status-

$\times$ side $\times$ time, treatment $\times$ side $\times$ time, status $\times$ treatment $\times$ side $\times$ time, and error. Data for incorporation of $\left[{ }^{3} \mathrm{H}\right]$ leucine into proteins were analysed using the model components of status, status (gilt), treatment status $\times$ treatment, status(gilt) $\times$ treatment, and error.

\section{Results}

\section{PGF secretion}

Endometrial tissues remained viable throughout the $5 \mathrm{~h}$ of perifusion as indicated by sustained PGF secretion (Fig. 1). Mean rates of endometrial PGF secretion, before heat stress, were higher $(P<0.01)$ from the myometrial than luminal side for Day 14 cyclic gilts (Fig. 1). In contrast, PGF secretion rates, before heat stress, were higher $(P<0.01)$ from the luminal than myometrial side for Day 14 pregnant gilts (Fig. 1). This resulted in a status $\times$ side interaction $(P<0.01)($ Period 1$)$.

Before the initiation of heat stress (Period 1), PGF secretion rates by endometria within each reproductive status and endometrial side were similar between treatment groups (Table 1). Elevation of perifusion temperature from 39 to $42^{\circ} \mathrm{C}$ (heat stress) induced a rapid and sustained increase in $\mathrm{PGF}$ secretion rates that varied depending upon reproductive status and endometrial side (Period 2; Fig. 1; Table 1; $P<0.01$; status $\times$ treatment $\times$ side interaction). Secretion of PGF in response to heat stress was greater from the myometrial side of endometrium from pregnant gilts $(P<0.01)$. Secretion rates of PGF during the first $2 \mathrm{~h}$ of heat stress (Period 2; Table 1) were increased $(P<0.01) 63 \%$ and $42 \%$ from the luminal side and $40 \%$ and $156 \%$ from the myometrial 


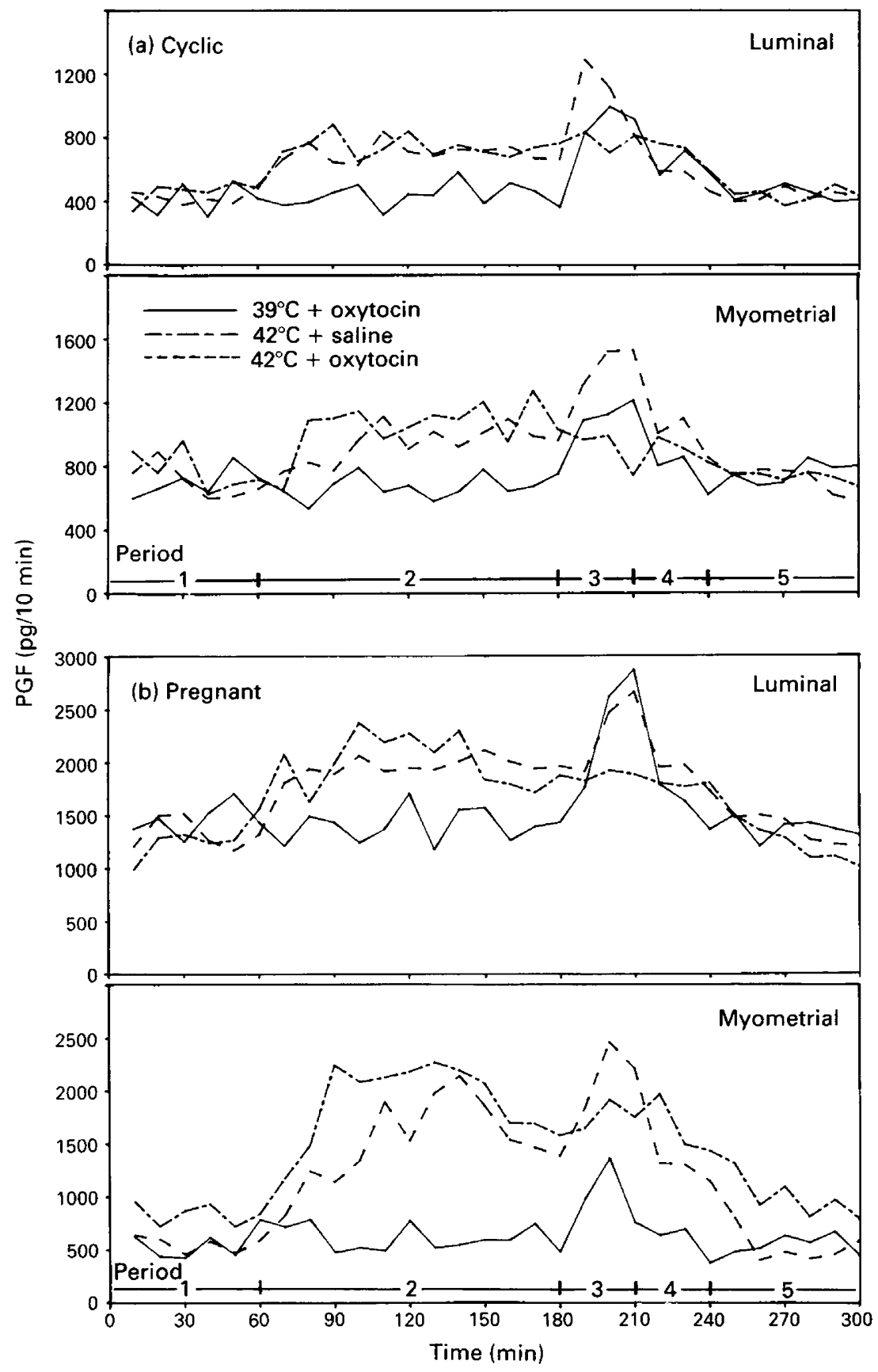

Fig. 1. Endometrial secretion rates of PGF from luminal and myometrial sides for (a) cyclic and (b) pregnant gilts at Day 14 after oestrus. Treatments were: (1) Control-oxytocin, $1 \mathrm{~h}$ at $39^{\circ} \mathrm{C}$, $2 \mathrm{~h}$ at $39^{\circ} \mathrm{C}, 0.5 \mathrm{~h}$ at $39^{\circ} \mathrm{C}$ with oxytocin, $0.5 \mathrm{~h}$ at $39^{\circ} \mathrm{C}$ and $1 \mathrm{~h}$ at $39^{\circ} \mathrm{C} ;(2)$ heat-oxytocin, $1 \mathrm{~h}$ at $39^{\circ} \mathrm{C}, 2 \mathrm{~h}$ at $42^{\circ} \mathrm{C}, 0.5 \mathrm{~h}$ at $42^{\circ} \mathrm{C}$ with oxytocin, $0.5 \mathrm{~h}$ at $42^{\circ} \mathrm{C}$ and $1 \mathrm{~h}$ at $39^{\circ} \mathrm{C}$; and (3) heatsaline, $1 \mathrm{~h}$ at $39^{\circ} \mathrm{C}, 2 \mathrm{~h}$ at $42^{\circ} \mathrm{C}, 0.5 \mathrm{~h}$ at $42^{\circ} \mathrm{C}, 0.5 \mathrm{~h}$ at $42^{\circ} \mathrm{C}$ and $1 \mathrm{~h}$ at $39^{\circ} \mathrm{C}$. 
side for cyclic and pregnant gilts, respectively (Table 1). This resulted in a disproportionate increase in PGF secretion from the myometrial side of endometrium from pregnant gilts in response to heat stress. During heat stress (Period 2), PGF secretion no longer differed between luminal and myometrial sides for endometrial tissue from pregnant gilts. However, PGF secretion remained higher from the myometrial than the luminal side for endometrium from cyclic gilts regardless of treatment (temperature).

Table 1. Endometrial secretion rates of PGF (pg/10 min mean \pm s.e.m.) by luminal and myometrial sides for pregnant and cyclic gilts at Day 14 after oestrus: treatment periods were: (1) $1 \mathrm{~h}$ at $39^{\circ} \mathrm{C}$; (2) $2 \mathrm{~h}$ at 39 or $42^{\circ} \mathrm{C}$; (3) $0.5 \mathrm{~h}$ at $39^{\circ} \mathrm{C}$ with oxytocin or at $42^{\circ} \mathrm{C}$ with saline or oxytocin; (4) $0.5 \mathrm{~h}$ at 39 or $42^{\circ} \mathrm{C}$; and $(5) 1 \mathrm{~h}$ at $39^{\circ} \mathrm{C}$

\begin{tabular}{|c|c|c|c|c|c|}
\hline \multirow[b]{2}{*}{ Treatment } & \multicolumn{5}{|c|}{ Perifusion treatment period } \\
\hline & $1^{\mathrm{a}}$ & $2^{b}$ & $3^{c}$ & $4^{c}$ & $5^{a}$ \\
\hline \multicolumn{6}{|l|}{ Pregnant $(\mathrm{N}=4)$} \\
\hline \multicolumn{6}{|l|}{ Luminal } \\
\hline $39^{\circ} \mathrm{C}-$ oxytocin & $1449 \pm 66$ & $1433 \pm 80$ & $2421 \pm 136$ & $1468 \pm 75$ & $1372 \pm 63$ \\
\hline $42^{\circ} \mathrm{C}$-oxytocin & $1329 \pm 81$ & $1781 \pm 89$ & $2003 \pm 105$ & $1767 \pm 111$ & $1353 \pm 73$ \\
\hline $42^{\circ} \mathrm{C}$-saline & $1276 \pm 65$ & $1901 \pm 117$ & $1642 \pm 96$ & $1591 \pm 90$ & $1289 \pm 70$ \\
\hline \multicolumn{6}{|l|}{ Myometrial } \\
\hline $39^{\circ} \mathrm{C}$-oxytocin & $582 \pm 87$ & $598 \pm 51$ & $1029 \pm 142$ & $681 \pm 90$ & $542 \pm 48$ \\
\hline $42^{\circ} \mathrm{C}$-oxytocin & $645 \pm 61$ & $1506 \pm 124$ & $2016 \pm 93$ & $1242 \pm 101$ & $636 \pm 54$ \\
\hline $42^{\circ} \mathrm{C}$-saline & $703 \pm 95$ & $1944 \pm 180$ & $1736 \pm 77$ & $1527 \pm 138$ & $716 \pm 97$ \\
\hline \multicolumn{6}{|l|}{ Cyclic $(\mathbf{N}=5)$} \\
\hline \multicolumn{6}{|l|}{ Luminal } \\
\hline $39^{\circ} \mathrm{C}$-oxytocin & $415 \pm 35$ & $536 \pm 33$ & $915 \pm 79$ & $522 \pm 37$ & $443 \pm 26$ \\
\hline $42^{\circ} \mathrm{C}$-oxytocin & $427 \pm 50$ & $731 \pm 50$ & $1075 \pm 79$ & $645 \pm 42$ & $436 \pm 19$ \\
\hline $42^{\circ} \mathrm{C}$-saline & $458 \pm 37$ & $714 \pm 47$ & $636 \pm 52$ & $695 \pm 58$ & $458 \pm 33$ \\
\hline \multicolumn{6}{|l|}{ Myometrial } \\
\hline $39^{\circ} \mathrm{C}-$ oxytocin & $782 \pm 37$ & $715 \pm 67$ & $1169 \pm 122$ & $798 \pm 59$ & $726 \pm 59$ \\
\hline $42^{\circ} \mathrm{C}-$ oxytocin & $755 \pm 79$ & $1035 \pm 68$ & $1455 \pm 98$ & $985 \pm 66$ & $802 \pm 29$ \\
\hline $42^{\circ} \mathrm{C}$-saline & $807 \pm 53$ & $1156 \pm 58$ & $975 \pm 51$ & $852 \pm 36$ & $797 \pm 27$ \\
\hline
\end{tabular}

Oxytocin (Period 3) induced a rapid increase in the secretion of PGF that varied depending upon reproductive status, endometrial side, and treatment (temperature) (Fig. 1; Table 1; $P<0.05$; status $\times$ treatment $\times$ side interaction). Endometrium (luminal and myometrial sides) from cyclic and pregnant gilts responded to oxytocin at either 39 or $42^{\circ} \mathrm{C}$. However, PGF secretion at $39^{\circ} \mathrm{C}$ from the luminal side remained higher than that from the myometrial side for endometrium from pregnant gilts, and the luminal response to oxytocin was greater than that from the myometrial side. In contrast, PGF secretion at $42^{\circ} \mathrm{C}$ did not differ between luminal and myometrial sides for endometrial tissue from pregnant gilts, and the response to oxytocin did not differ with endometrial side. For cyclic gilts, myometrial responses to oxytocin were greater than luminal responses when perifused at either 39 or $42^{\circ} \mathrm{C}$, and PGF secretion was greater from the myometrial than luminal side regardless of perifusion temperature.

After oxytocin treatment (Period 4), secretion rates of PGF declined rapidly to pre-oxytocin rates of secretion (Period 2, Table 1). Heat stress $\left(42^{\circ} \mathrm{C}\right)$ resulted in increased secretion rates of PGF that varied depending upon reproductive status, endometrial side and treatment (temperature) (status $\times$ treatment $\times$ side interaction; $P<0.01$; Table 1). Secretion of PGF remained higher from the myometrial side of endometrium from cyclic gilts regardless of perifusion temperature or previous oxytocin treatment during Period 3. In contrast, PGF secretion for endometrium from 
pregnant gilts, perifused at $39^{\circ} \mathrm{C}$, remained higher from the luminal side. However, PGF secretion for endometrium from pregnant gilts, perifused at $42^{\circ} \mathrm{C}$, did not differ between luminal and myometrial sides when previously treated with saline during Period 3, whereas luminal secretion was greater when previously treated with oxytocin during Period 3. Indeed, the myometrial side of endometrium from pregnant gilts was less able to respond to additional heat stress following oxytocin treatment during the previous period (Period 3) than was the saline-treated myometrial side (Table 1; Fig. 1).

When perifusion temperatures were reduced from 42 to $39^{\circ} \mathrm{C}($ Period 5), PGF secretion rates declined $(P<0.01)$ to pre-heat stress rates (Period 1) within $30 \mathrm{~min}$ of the temperature change (Fig. 1). Mean secretion rates of PGF did not differ during Period 5 between treatments for each status and endometrial side (Table 1). Secretion rates of PGF during period 5 were similar to those observed during Period 1.

\section{Incorporation of $I^{3}$ H]leucine into endometrial proteins}

Incorporation of $\left[{ }^{3} \mathrm{H}\right]$ leucine into secreted and tissue proteins was examined quantitatively by TCA precipitation. Incorporations into secreted (2942 and $1258 \mathrm{~d} . \mathrm{p} . \mathrm{m} . / \mathrm{mg}$ tissue, respectively) and tissue (27 222 and 9702 d.p.m./mg tissue, respectively) proteins were greater $(P<0.01)$ for endometrium from pregnant than cyclic gilts at $39^{\circ} \mathrm{C}$. Heat stress $\left(42^{\circ} \mathrm{C}\right)$ did not alter incorporation into secreted proteins regardless of reproductive status (pregnant, 3233 d.p.m./mg; cyclic, 1307 d.p.m./ $\mathrm{mg}$ ). However, heat stress $\left(42^{\circ} \mathrm{C}\right)$ decreased incorporation into tissue proteins for endometrium from pregnant gilts (19807 d.p.m./mg tissue), but did not alter incorporation into tissue proteins for cyclic gilts (10 406 d.p.m./mg tissue) (treatment $\times$ status; $P<0.01$ ).

Polyacrylamide gel electrophoresis was utilized to examine qualitative differences in incorporation of $\left[{ }^{3} \mathrm{H}\right]$ leucine into secreted and tissue proteins (equal d.p.m. utilized for each electrophoretogram). The array of $\left[{ }^{3} \mathrm{H}\right]$ leucine labelled endometrial tissue proteins (Fig. 2) present on one-dimensional fluorographs did not differ qualitatively between pregnant and cyclic gilts. However, heat stress enhanced the relative radiolabelling of tissue proteins of $M_{\mathrm{r}} 70000$ and 90000 (possibly heat shock proteins) regardless of reproductive status (Fig. 2). The major $\left[{ }^{3} \mathrm{H}\right]$ leucinelabelled secreted proteins were in an $M_{\mathrm{r}} 30000-95000$ range, and pig serum albumin (PSA, $M_{\mathrm{r}} 69000$ ) was present as a major unlabelled protein component regardless of reproductive status (Fig. 3). The presence of PSA probably reflects leaching of serum components into the medium. Unlabelled PSA appeared to be more prevalent in media from cyclic gilts, but this may have been due to the larger volumes of medium required to yield equivalent radiolabel activity to that utilized for pregnant gilts. Increased levels of unlabelled PSA, present in medium from cyclic gilts, are indicated by the increased distortion of protein patterns on the fluorographs (Fig. 3). Radiolabelled secreted proteins of $M_{\mathrm{r}} 70000$ may be enhanced in medium for endometrial explants from pregnant gilts. However, the PSA-induced distortion in protein patterns for cyclic gilts does not enable a clear comparison. Heat stress did not alter the array of $\left[{ }^{3} \mathrm{H}\right]$ leucine-labelled secretory proteins regardless of reproductive status (Fig. 3). However, there was a decreased intensity of radiolabelled proteins of $M_{\mathrm{r}} 35000$ for endometrium from pregnant compared to cyclic gilts (see arrows Fig. 3).

\section{Discussion}

Previous results (Gross et al., 1988a) demonstrated that secretion of PGF during early pregnancy in gilts is redirected from the uterine vasculature (towards the myometrium; endocrine secretion) towards the uterine lumen (exocrine secretion). This reorientation of PG secretion in pregnant gilts results in decreased maternal levels of PGF and, therefore, a reduction in the luteolytic signal. Data from the present study reconfirm this reorientation in the direction of endometrial PGF secretion in pregnant gilts. 


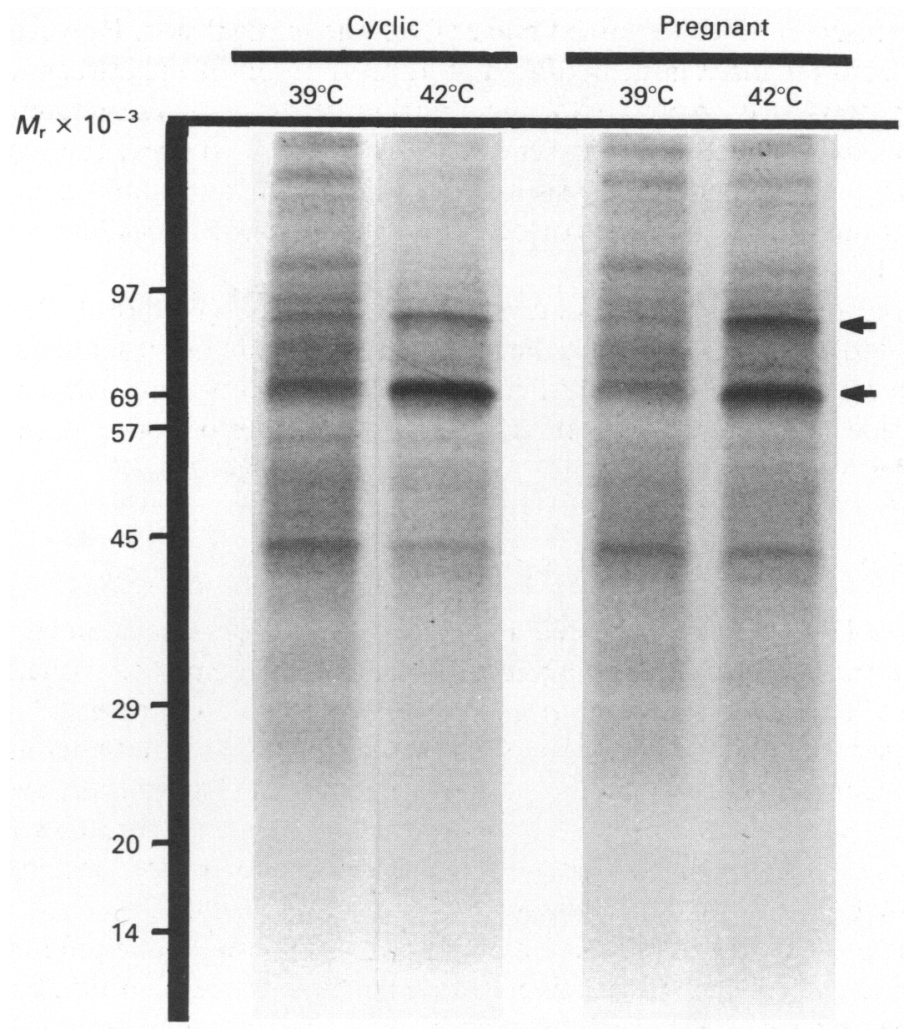

Fig. 2. Fluorograph of a one-dimensional SDS-polyacrylamide gel electrophoretogram of solubilized tissue from endometrium of a cyclic and a pregnant gilt at Day 14 after oestrus cultured in the presence of $\left[{ }^{3} \mathrm{H}\right]$ leucine for $8 \mathrm{~h}$ at thermoneutral $\left(39^{\circ} \mathrm{C}\right)$ or heat stress $\left(42^{\circ} \mathrm{C}\right)$ temperatures. An aliquant of each sample of solubilized tissue (100 000 d.p.m.) was lyophilized, dissolved in dissociating buffer and separated on a $12.5 \%(\mathrm{w} / \mathrm{v})$ polyacrylamide gel in the presence of reducing agent. Note that the array of radiolabelled proteins in tissue did not differ for endometrium from cyclic and pregnant pigs. Note the increased intensity of proteins of $M_{\mathrm{r}} 70000$ and 90000 (see arrows) in response to heat stress (possibly heat shock proteins) regardless of reproductive status.

Increased secretion of PGF in response to heat stress in vitro by endometrial explants from cattle at Day 17 of pregnancy has been reported (Putney et al., 1988b). In-vivo heat stress of gilts between Days 8 and 16 of pregnancy increased concentrations of PGFM in plasma and subsequently induced luteolysis (Hoagland \& Wettemann, 1984; Wettemann et al., 1988). In the present study, heat stress induced a rapid and sustained increase in endometrial secretion rates of PGF by luminal and myometrial sides both for pregnant and cyclic gilts. However, heat stress $\left(42^{\circ} \mathrm{C}\right)$ induced a disproportionate increase in PGF secretion from the myometrial side of endometrium from pregnant gilts. Likewise, the myometrial side of endometrium from pregnant gilts becomes more responsive to oxytocin when heat stressed. An endocrine orientation (towards the myometrium) of PGF secretion is normally present for cyclic gilts and is critical for the availability of PGF for luteolysis (Bazer \& Thatcher, 1977; Gross et al., 1988a). However, secretion of PGF is normally greater from the luminal surface (exocrine orientation), and the luminal surface is normally more responsive to oxytocin during early pregnancy in pigs (Gross et al., 1988a). Therefore, a disproportionate increase in PGF secretion from the myometrial side of endometrium from pregnant gilts in response to heat stress might redirect PGF secretion from the normal exocrine orientation to an 


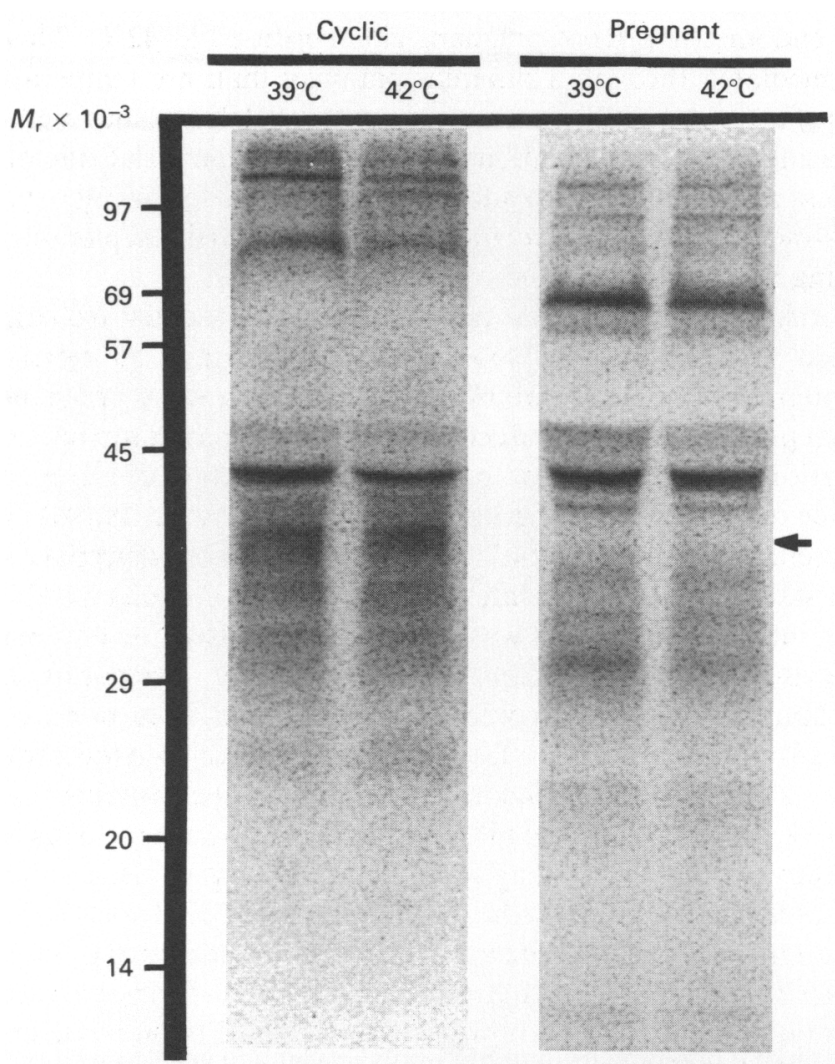

Fig. 3. Fluorograph of a one-dimensional SDS-polyacrylamide gel electrophoretogram of dialysed medium from endometrium of a cyclic and a pregnant gilt at Day 14 after oestrus cultured in the presence of $\left[{ }^{3} \mathrm{H}\right]$ leucine for $8 \mathrm{~h}$ at thermoneutral $\left(39^{\circ} \mathrm{C}\right)$ or heat stress $\left(42^{\circ} \mathrm{C}\right)$ temperatures. An aliquant of each sample of culture medium ( 100000 d.p.m.) was lyophilized, dissolved in dissociating buffer and separated on a $12.5 \%(\mathrm{w} / \mathrm{v})$ polyacrylamide gel in the presence of reducing agent. Note the decreased intensity of proteins of $M_{\mathrm{r}} 35000$ for pregnant compared to cyclic gilts (see arrow). Heat stress did not alter the secretion of radiolabelled proteins regardless of reproductive status.

endocrine orientation. Increased secretion from the myometrial side, in response to heat stress, might allow PGF to reach the CL and compromise the establishment of pregnancy.

Increased PGF secretion by endometrium exposed to heat stress may be due to alterations in cellular membranes which result in increased mobilization of substrate for prostaglandin biosynthesis. The primary cellular site for the action of heat stress is cellular membranes (Bowler et al., 1973; Hahn, 1982). Increased ambient temperature increases membrane fluidity, phospholipase activity and phosphoinositide turnover (Calderwood et al., 1987), which would increase the release of arachidonic acid (Flint et al., 1986). Arachidonic acid is the principal substrate for PGF synthesis in endometrium before initiation of endometrial PGF synthesis and luteolysis (Hansel et al., 1975; Shemesh \& Hansel, 1975). Exogenous arachidonic acid also stimulates PG synthesis by endometrial tissues in vitro (Thatcher et al., 1984). Therefore, increased PGF secretion in response to heat stress may be due to increased availability of substrate for PG synthesis.

Oxytocin also increases the availability of substrate for endometrial PG synthesis (Flint et al., 1986). Indeed, the present study demonstrates increased PGF secretion in response to oxytocin regardless of reproductive status. Oxytocin also augmented the increased secretion of PGF observed during heat stress. In addition, this increase in response to heat stress was greatest for the 
myometrial side of endometrium from pregnant gilts perifused at $42^{\circ} \mathrm{C}$. Therefore, the effects of oxytocin might be mediated through a different pathway than are temperature effects. Alternatively, heat stress may not maximally increase substrate availability such that oxytocin would still be capable of increasing substrate availability. Indeed, the myometrial side of endometrium from pregnant gilts was less able to respond to additional heat stress following oxytocin treatment than following saline treatment. These data may indicate at least a partial depletion of substrate for PGF biosynthesis following both heat stress and oxytocin treatments.

Endometrial protein secretions provide nutrients that are essential for conceptus development (Bazer, 1975). Indeed, results from the present study demonstrate an increase in the amount of radiolabelled endometrial tissue and secretory proteins during early pregnancy. Therefore, alterations in endometrial protein synthesis induced by heat stress may contribute to pregnancy failure. A differential regulation between secreted and tissue incorporation of $\left[{ }^{3} \mathrm{H}\right]$ leucine has been shown for endometrial tissue during early pregnancy for cows (Gross et al., 1988d) and sheep (Godkin et al., 1984). In the present study, a differential regulation between endometrial tissue from animals of cyclic and pregnant status appears to occur, as measured by TCA-precipitable protein. Incorporation of $\left[{ }^{3} \mathrm{H}\right]$ leucine into tissue proteins was selectively increased for endometrial explants from pregnant gilts. Likewise, heat stress differentially reduced label incorporation into tissue proteins for endometrial explants from pregnant compared to cyclic gilts. Incorporation of $\left[{ }^{3} \mathrm{H}\right]$ leucine into intracellular proteins is much higher than for incorporation into secreted proteins (approximately $10 \%$ of tissue proteins). Furthermore, incorporation into tissue proteins for endometrium from pregnant gilts is $280 \%$ greater than for endometrium from cyclic gilts. This higher incorporation for endometrium from pregnant gilts may increase the ability to detect alterations due to heat stress. None the less, the present results indicate a decrease in the intensity of proteins of $M_{\mathrm{r}} 35000$ for pregnant compared to cyclic gilts. Heat stress $\left(42^{\circ} \mathrm{C}\right)$ increased the intensity of $\left[{ }^{3} \mathrm{H}\right]$ leucinelabelled tissue proteins of $M_{\mathrm{r}} 70000$ and 90000 (possibly heat shock proteins) detected on onedimensional fluorographs regardless of reproductive status. Endometrial explants incubated at $39^{\circ} \mathrm{C}$ also produced radiolabelled tissue proteins of $M_{\mathrm{r}} 70000$ and 90000 , but at reduced intensities compared to $42^{\circ} \mathrm{C}$. Similar proteins, heat shock proteins, have been described for other heatstressed mammalian tissues (Nover, 1984; Putney et al., 1988b). Heat shock proteins are believed to play a role in cellular homeostasis and thermotolerance during periods of stress. Their involvement, if any, in prostaglandin synthesis is not known. However, heat shock proteins may increase endometrial prostaglandin secretion and/or alter the direction of this secretion in gilts exposed to heat stress conditions.

This study was supported in part by USDA grants 86-CRSR-2-2106 and 85-CRSR-1-1871. This is Journal series no. 9111 of the Florida Agricultural Experimental Station.

\section{References}

Basha, S.M.M., Bazer, F.W. \& Roberts, R.M. (1980) Effect of the conceptus on quantitative and qualitative aspects of uterine secretion in pigs. J. Reprod. Fert. 60, $41-48$.

Bazer, F.W. (1975) Uterine protein secretions: relationship to development of the conceptus. J. Anim. Sci. 41, 1376-1382.

Bazer, F.W. \& Thatcher W.W. (1977) Theory of maternal recognition of pregnancy in swine based on estrogen controlled endocrine versus exocrine secretion of prostaglandin $\mathrm{F}-2 \alpha$ by the uterine endometrium. Prostaglandins 14, 397-401.

Bazer, F.W., Vallet, J.L., Harney, J.P., Gross, T.S. \& Thatcher, W.W. (1989) Comparative aspects of maternal recognition of pregnancy between sheep and pigs. J. Reprod. Fert., Suppl. 37, 85-89.
Bowler, K., Duncan, C.J., Gladwell, R.T. \& Davison, T.F. (1973) Cellular heat injury. Comp. Biochem. Physiol. 45A, 44I-450.

Calderwood, S.K., Stevenson, M.A. \& Hahn, G.M. (1987) Heat stress stimulates inositol triphosphate release and phosphorylation of phosphoinositides in CHO and Balb C 3T3 cells. J. cell. Physiol. 130, 369-376.

Chamberlain, J.P. (1979) Fluorographic detection of radioactivity in polyacrylamide gels with the water soluble fluor, sodium salicylate. Analyt. Biochem. 98, 132-135.

Dutt, R.H. (1963) Critical period for early embryo mortality in ewes exposed to high ambient temperature. J. Anim. Sci. 22, 713-719.

Flint, A.P.F., Leat, W.M.F., Sheldrick, E.L. \& Stewart, H.J. (1986) Stimulation of phosphoinositide 
hydrolysis by oxytocin and the mechanism by which oxytocin controls prostaglandin synthesis in the ovine endometrium. Biochem. J. 237, 797-805.

Godkin, J.D., Bazer, F.W. \& Roberts, R.M. (1984) Ovine trophoblast protein 1 , and early secreted blastocyst protein, binds specifically to uterine endometrium and affects protein synthesis. Endocrinology 114, 120-130.

Gross, T.S., Lacroix, M.C., Bazer, F.W., Thatcher, W.W. \& Harney, J.P. (1988a) Prostaglandin secretion by perifused porcine endometrium: further evidence for an endocrine versus exocrine secretion of prostaglandins. Prostaglandins 35, 327-341.

Gross, T.S., Thatcher, W.W., Hansen, P.J., Johnson, J.W. \& Helmer, S.D. (1988b) Presence of an intracellular endometrial inhibitor of prostaglandin synthesis during early pregnancy in the cow. Prostaglandins 35, 359-378.

Gross, T.S., Thatcher, W.W., Lacroix, M.C. \& Hansen, P.J. (1988c) Prostaglandin secretion by perifused bovine endometrium: secretion towards the myometrial and luminal side at Day 17 post-estrus as altered by pregnancy. Prostaglandins 35, 343-357.

Gross, T.S., Plante, C., Thatcher, W.W., Hansen, P.J., Helmer, S.D. \& Putney, D.J. (1988d) Bovine conceptus secretory proteins alter endometrial prostaglandin and protein synthesis in vitro. Biol. Reprod. 39, 977-988.

Hahn, G.M. (1982) Hyperthermia and Cancer, pp. 8-22. Plenum Press, New York.

Hansel, W., Shemesh, M., Hixon, J. \& Lukaszewska, J. (1975) Extraction, isolation and identification of a luteolytic substance from bovine endometrium. Biol. Reprod. 13, 30-37.

Hoagland, T.A. \& Wettemann, R.P. (1984) Influence of elevated ambient temperature after breeding on plasma corticoids, estradiol and progesterone in gilts. Theriogenology 22, 15-24.

Kennedy, T.G. (1985) Evidence for the involvement of prostaglandins throughout the decidual cell reaction in the rat. Biol. Reprod. 34, 140-146.

Lacroix, M.C. \& Kann, G. (1983) Discriminating analysis of in vitro prostaglandin release by myometrial and luminal sides of the ewe endometrium. Prostaglandins 25, 853-869.

Laemmli, U.K. (1970) Cleavage of structural proteins during the assembly of bacteriophage T4. Nature, Lond. 227, 680-685.
Mans, R.J. \& Novelli, D. (1961) Measurement of the incorporation of radioactive amino acids into proteins by a filter-paper disk method. Archs Biochem. Biophys. 94, 48-53.

Nover, L. (1984) Heat Shock Response in Eucaryotic Cells. Springer-Verlag, New York.

Putney, D.J., Drost, M. \& Thatcher, W.W. (1988a) Embryonic development in superovulated dairy cattle exposed to elevated ambient temperatures between days 1 to 7 post insemination. Theriogeno$\log y$ 30, 195-206.

Putney, D.J., Malayer, J.R., Gross, T.S., Hansen, P.J., Thatcher, W.W. \& Drost, M. (1988b) Heat shock induced alterations in prostaglandin and protein secretion by bovine conceptuses and uterine endometrium. Biol. Reprod. 39, 717-728.

Roberts, R.M., Baumbach, G.A., Buhi, W.C., Denny, J.B., Fitzgerald, L.A., Babelyn, K.M. \& Horst, M.N. (1984) Analysis of membrane polypeptides by two dimensional polyacrylamide gel electrophoresis. In Molecular and Chemical Characterization of Membrane Receptors, pp. 63-113. Eds C. J. Venter \& L. C. Harrison. Alan R. Liss, New York.

SAS User's Guide (1985) Statistics. SAS Institute Inc., Cary, NC.

Shemesh, M. \& Hansel, W. (1975) Levels of prostaglandin F (PGF) in bovine endometrium, uterine venous, ovarian arterial and jugular plasma during the estrous cycle. Proc. Soc. exp. Biol. Med. 148, 123126.

Thatcher, W.W. (1974) Effects of season, climate and temperature on reproduction and lactation. J. Dairy Sci. 57, 360-368.

Thatcher, W.W., Bartol, F.F., Knickerbocker, J.J., Curl, J.S., Wolfenson, D., Bazer, F.W. \& Roberts, R.M. (1984) Maternal recognition of pregnancy in cattle. $J$. Dairy Sci. 67, 2797-2811.

Trujano, M. \& Wrathall, A.E. (1985) Developmental abnormalities in cultured early porcine embryos induced by hyperthermia. Br. vet. J. 141, 603-610.

Wettemann, R.P., Bazer, F.W., Thatcher, W.W., Caton, D. \& Roberts, R.M. (1988) Conceptus development, uterine response, blood gases and endocrine function of gilts exposed to increased ambient temperature during early pregnancy. Theriogenology 30, 57-66.

Received 28 June 1988 